\title{
SIZE AND GROWTH VARIATION AT MATURITY OF TWO COMMON SQUID SPECIES IN THE SOUTH CHINA SEA
}

\author{
Rashedul Islam ${ }^{1 \star}$, Siriporn Pradit ${ }^{1}$, Sukree Hajisamae ${ }^{2}$, Permsak Perngmak $^{3}$, Hisam Fazrul ${ }^{4}$ \\ ${ }^{1}$ Marine and Coastal Resources Institute, Prince of Songkla University, Thailand \\ ${ }^{2}$ Faculty Science and Technology, Prince of Songkla University, Thailand \\ ${ }^{3}$ Southern Marine Fisheries and Development Centre, Songkhla, Thailand \\ ${ }^{4}$ School of Fisheries and Aquaculture Science, University Malaysia Terengganu, Malaysia \\ ${ }^{*}$ E-mail: rashed.pstu10@gmail.com \\ Tel: +6674282329 (internal 2329), 074-282320-9; Fax: 074212782
}

\begin{abstract}
This study is aimed to observe the variation in size and growth change at maturity stage of both sexes for two common loliginidae squid species; Photololigo chinensis and $P$. duvaucelii in the lower part of Gulf of Thailand. Males maturity stage-III of both squid species displayed

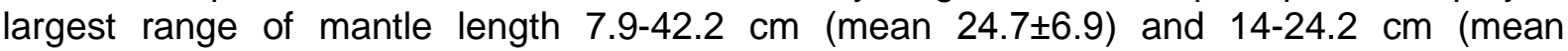
$19.7 \pm 2.3$ ) for $P$. chinensis and $P$. duvaucelii respectively. Similarly, female maturity stage-I were showed largest range of mantle length; $4.6-18.2 \mathrm{~cm}$ (mean $10.8 \pm 3.4 \mathrm{~cm}$ ) and $4.9-16 \mathrm{~cm}$ (mean $12.8 \pm 2.9 \mathrm{~cm}$ ) for $P$. chinensis and $P$. duvaucelii respectively. Some maturity stage-III was smaller than maturity stage-II for males $P$. chinensis; some maturity stage-III females of $P$. duvaucelii showed smaller size than maturity stage-II. All of three maturity stages of both sexes exhibited negative allometric growth $(b<3)$ and growth coefficient value " $b$ " inversely related with imposing their new maturity stage. Therefore, this study results can be used to help the fishery managers which can be used for maintain sustainable condition of loliginid resources in the Gulf of Thailand and leading to a greater boost in the economy of Thailand.
\end{abstract}

\section{KEY WORDS}

Gulf of Thailand, Loliginidae, maturity stage, allometric, correlation.

The Gulf of Thailand is an inlet of the South China Sea which inhibits the exchange of water and considered as an ecologically distinct subset area of the South China Sea (Piyakarnchana, 1989; Pauly and Christensen, 1993).The Gulf of Thailand is located in latitudes $5^{\circ} 00^{\prime}$ and $13^{\circ} 30^{\prime} \mathrm{N}$ and longitudes $99^{\circ} 00^{\prime}$ and $106^{\circ} 00^{\prime} \mathrm{E}$ with $720 \mathrm{~km}$ length and maximum depth $84 \mathrm{~m}$ (Cheevaporn and Menasveta, 2003). It is a high abundant resources area for Loliginidae cephalopods species where two species; Photololigo chinensis (Gray, 1849) are most abundant and Photololigo duvaucelii (d'Orbigny, 1835) is second abundant species (dominant in the Andaman Sea Coast) in the Gulf of Thailand (Chotiyaputta, 1993; Chantawong and Suksawaet, 1997). Both squid species are Indo-Pacific and well distributed in the Indian Ocean and the South China Sea between $30-170 \mathrm{~m}$ depth range and large aggregation during spawning season and (Silas et al., 1982).

It was recorded that about $15-40 \%$ of the trawl catches were $P$. chinensis in Gulf of Thailand and available in 15-170 m depth range (Jereb and Roper, 2010) and a year-round spawning season with two main peaks time March-June and August-November; a length at $50 \%$ maturity of $16 \mathrm{~cm}$ and $14 \mathrm{~cm}$ mantle length (ML) for males and females, respectively (Chotiyaputta, 1993). Subsequently, it was reported that $P$. chinensis earlier mature happen during the warmer summer period than in the cooler winter period which suggesting that maturity is governed more by individual size than by age (Jackson, 1993). It was reported as largest loliginid species in the Indo-Pacific region and mantle length up to $49 \mathrm{~cm}$ for males and $31 \mathrm{~cm}$ for females (Voss and Williamson, 1971).

$P$. duvaucelii spawning depends on the southwest (SW) and northeast (NE) monsoons in the western part of the Gulf of Thailand (Supongpan and Sinoda, 1998). Size at 50\% 
maturity; $9-13 \mathrm{~cm} \mathrm{ML}$ for females and $7-15 \mathrm{~cm} \mathrm{ML}$ for males and the observations on growth after sexual maturity is reached, indicating an extended reproductive phase within the life cycle (Mohamed, 1993). It was reported from Thailand, females grow faster than males; though, finally males become a larger size than females and maximum $\mathrm{ML}$ of males was 32 cm (Chotiyaputta, 1993). The length-weight relationships are important for accessing knowledge of growth style (Petrakis and Stergiou, 1995).

Therefore, this study is aimed to observe the size range and growth pattern of $P$. chinensis and $P$. duvaecelii in the different stage of maturity for both sexes.

\section{MATERIALS AND METHODS}

Sampling method. The sampling sites were situated lower part of Gulf of Thailand (Figure 1) and bottom trawl net was operated by "MV PRAMONG 9" research vessel to collect the samples during April -June, 2015. The depth range were recorded 17-49 $\mathrm{m}$ and the target species $P$. chinensis and $P$. duvaucelii were randomly selected, kept frozen and brought back to the laboratory for further analysis. Some samples were collected from local fishermen.

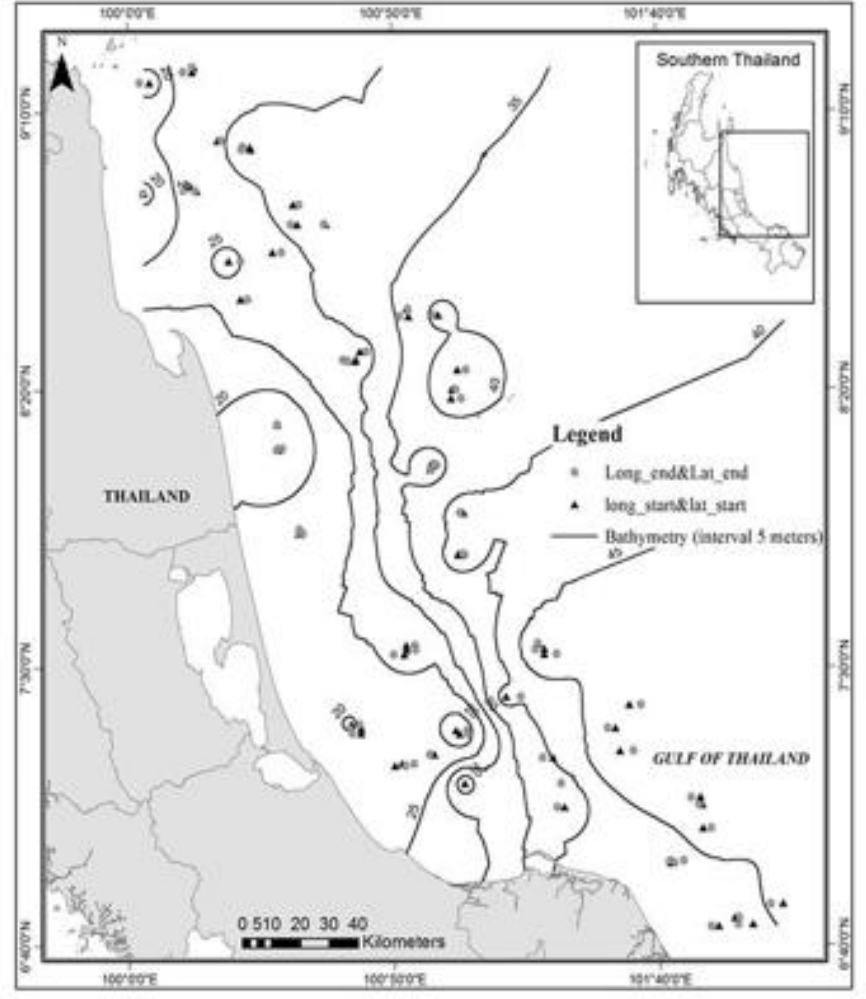

Figure 1 - Study area from where sample collected

Data processing and analysis. The macroscopic scales were assessed to identify sexes and stage of maturity (Jereb and Ragonese., 1995). Both males and females were assigned into 3 stages; immature = stage-I, maturing = stage-II and mature = stage-III. For the males, stage- $I=$ Small and inconspicuous gonad with hardly visible testis and no organizing of hectocotylus. Stage- $I I=$ The testis is a white, flat, lanceolate body. A welldeveloped Spermatophoric sac (SS) found and clear visible penis and hectocotylus completely formed. Stage-III = The testis is conspicuous, fusiform and slightly yellowish and spermatophores filled in the SS.

Females were assigned these 3 stages of maturity according to their nidamental gland (NG), ovary and eggs; Stage-I = Thin and almost transparent NG and threadlike ovary is visible; Stage-II = Whitish and well-formed NG formed but do not cover the underlying 
visceral mass. The ovary conspicuously developed and granular but does not occupy all the posterior half of the mantle cavity. Stage-III = Large and ripe, milk-white NG and almost completely cover the visceral mass. The specimens were too small couldn't identify the sex of these samples which assigned as 'juveniles' or 'unsexed'.

The dorsal mantle length $(\mathrm{ML})$ was measured in $\mathrm{cm}$ unit and weight in $\mathrm{g}$ unit. The length-weight relationships (LWR) were tested by using the least square method (Le Cren., 1951) for every stage of maturity of both sexes for both species to observe their growth pattern during different maturity stages. The equation was as followed (Eq. 1):

$$
\mathrm{BW}=\mathrm{a} M L^{\mathrm{b}}
$$

Where, BW is the body weight, ML is the mantle length, while ' $a$ ' and 'b' are constants.

Statistical analysis. Regression and correlation were performed between ML and BW. Standard deviation (SD), average, max and min were also calculated. All of the data were analyzed by using certain statistical tool in Microsoft Excel.

\section{RESULTS AND DISCUSSION}

\section{Maturation:}

Males. The total male samples of $P$. chinensis were 148; and 89, 46 and 49 were the number of males stand for stage-1, with stage- 2 and stage- 3 respectively. Largest range in mantle length for stage-III 7.9-42.2 cm and lowest range in mantle length for stage-II 10.5$23.1 \mathrm{~cm}$ (Table 1). Some mature stage-III males were smaller than mature stage-II (Figure 2A). A total 179 of males for $P$. duvaucelii and this species stage-III also showed largest range in mantle length $7.3-22 \mathrm{~cm}$ as like as found for $P$. chinensis species (Table 1 and Figure 2C).

Table 1 - The size range and mean size of males and females for maturity stage-1, stage- 2 and stage- 3 of $P$. chinensis and $P$. duvaucelii squid specimens

\begin{tabular}{|c|c|c|c|c|}
\hline \multirow{3}{*}{ Stage of Maturity } & \multicolumn{4}{|l|}{ P. chinensis } \\
\hline & \multicolumn{2}{|l|}{ Male } & \multicolumn{2}{|l|}{ Female } \\
\hline & Size range $(\mathrm{cm})$ & Mean \pm SD & Size range $(\mathrm{cm})$ & Mean \pm SD \\
\hline Stage 1 & $4.4-16.8$ & $9.2 \pm 2.3$ & $4.6-18.2$ & $10.8 \pm 3.4$ \\
\hline Stage 2 & $10.5-23.1$ & $14.6 \pm 3.5$ & $9.7-19.4$ & $16.3 \pm 3.3$ \\
\hline \multirow[t]{2}{*}{ Stage 3} & $7.9-42.2$ & $24.7 \pm 6.9$ & $14-24.2$ & $19.7 \pm 2.3$ \\
\hline & P. duvaucelii & & & \\
\hline Stage 1 & $5-16.9$ & $11.7 \pm 3.6$ & $4.9-16$ & $12.8 \pm 2.9$ \\
\hline Stage 2 & $5.2-17$ & $10.7 \pm 3.5$ & $8-14.7$ & $10.4 \pm 1.8$ \\
\hline Stage 3 & 7.3-22 & $11.6 \pm 3.6$ & 7.3-17.1 & $11.0 \pm 2.4$ \\
\hline
\end{tabular}

Females. Among 113 total number of female $P$. chinensis squids, the number of maturity stage-I, stage-II and stage-III were 66, 14 and 33 respectively. This species, maturity stage-I showed the largest range of mantle length $4.6-18.2 \mathrm{~cm}$; while stage-II and stage-III displayed same difference of mantle length but higher mantle length found for maturity stage-III (Table 1 and Figure $2 \mathrm{~B}$ ). The total number of females $P$. duvaucelii were 138; representing number 63, 37 and 38 for stage-I, stage-II and stage-III respectively. Highest range in mantle length noticed for female maturity stage-I and range was $4.9-16 \mathrm{~cm}$ (Table I). It was found some female maturity stage-II were larger size in mantle length than female maturity stage-III (Figure 2D).

Growth pattern of maturity stage. In all maturity stage of males and females of both species showed significant correlation $(p<0.01)$. Coefficient "b" value was 0.73 to 0.97 for $P$. chinensis and 0.87 to 0.98 for $P$. duvaucelii (Table 2) and growth rates of stage-III were much slower than the stage-I by representing lower value of growth coefficient "b" value. However, growth rates of all stages indicated negative allometry. Coefficient "b" value of 
stage-I were consistently showed highest degree for both males and females of both $P$. chinensis and $P$. duvaucelii squid (Table 2 ).
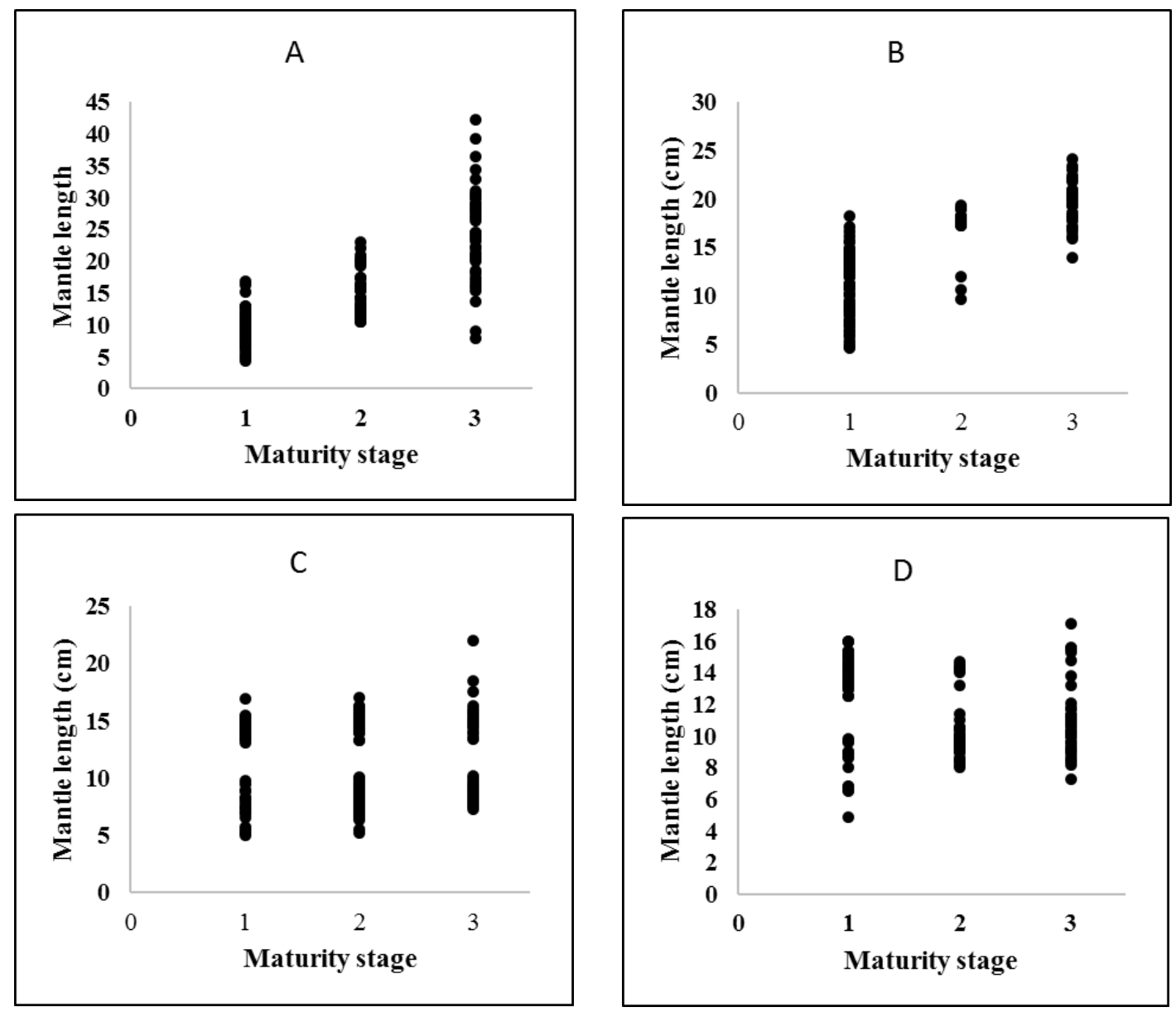

Figure 2 - The relationship between maturity stage and mantle length of both sexes for of $P$. chinensis $(\mathrm{A}, \mathrm{B}=$ males, females respectively for $P$. chinensis) and $P$. duvaucelii $(\mathrm{C}, \mathrm{D}==$ males, females respectively for $P$. duvaucelii)

Table 2 - LWR relationship of different stages of maturity of two squid species $P$. chinensis and $P$. duvaucelii in the Gulf of Thailand (N: sample size; $b$ : slope and $r^{2}$ correlation coefficient)

\begin{tabular}{lllllll}
\hline Species & Maturity stage & $\mathrm{N}$ & LWR Equation & Slope (b) & Coefficient (r2) & Growth pattern \\
\hline P. chinensis & Stage-1 (M) & 89 & $\mathrm{y}=0.195 \mathrm{x}^{2.246}$ & 2.256 & 0.89 & Allometric $(-)$ \\
& Stage-2 (M) & 46 & $\mathrm{y}=0.333 \mathrm{x}^{2.063}$ & 2.063 & 0.93 & Allometric $(-)$ \\
& Stage-3 (M) & 49 & $\mathrm{y}=1.053 \mathrm{x}^{1.671}$ & 1.671 & 0.95 & Allometric $(-)$ \\
& Stage-1 (F) & 66 & $\mathrm{y}=0.151 \mathrm{x}^{2.381}$ & 2.381 & 0.97 & Allometric $(-)$ \\
& Stage-2 (F) & 14 & $\mathrm{y}=0.302 \mathrm{x}^{2.142}$ & 2.142 & 0.97 & Allometric $(-)$ \\
& Stage-3 (F) & 33 & $\mathrm{y}=0.836 \mathrm{x}^{1.820}$ & 1.820 & 0.73 & Allometric $(-)$ \\
\hline P. duvaucelii & Stage-1 (M) & 49 & $\mathrm{y}=0.054 \mathrm{x}^{2.1 / 4}$ & 2.774 & 0.98 & Allometric $(-)$ \\
& Stage-2 (M) & 81 & $\mathrm{y}=0.129 \mathrm{x}^{2.415}$ & 2.415 & 0.97 & Allometric $(-)$ \\
& Stage-3 (M) & 49 & $\mathrm{y}=0.194 \mathrm{x}^{2.231}$ & 2.231 & 0.97 & Allometric $(-)$ \\
& Stage-1 (F) & 63 & $\mathrm{y}=0.055 \mathrm{x}^{2.180}$ & 2.780 & 0.97 & Allometric $(-)$ \\
& Stage-2 (F) & 37 & $\mathrm{y}=0.090 \mathrm{x}^{2.618}$ & 2.618 & 0.90 & Allometric $(-)$ \\
& Stage-3 (F) & 38 & $\mathrm{y}=0.294 \mathrm{x}^{2.141}$ & 2.141 & 0.87 & Allometric $(-)$ \\
\hline
\end{tabular}

Note: $M=$ male, $F=$ female, $y=B W, x=M L$. 

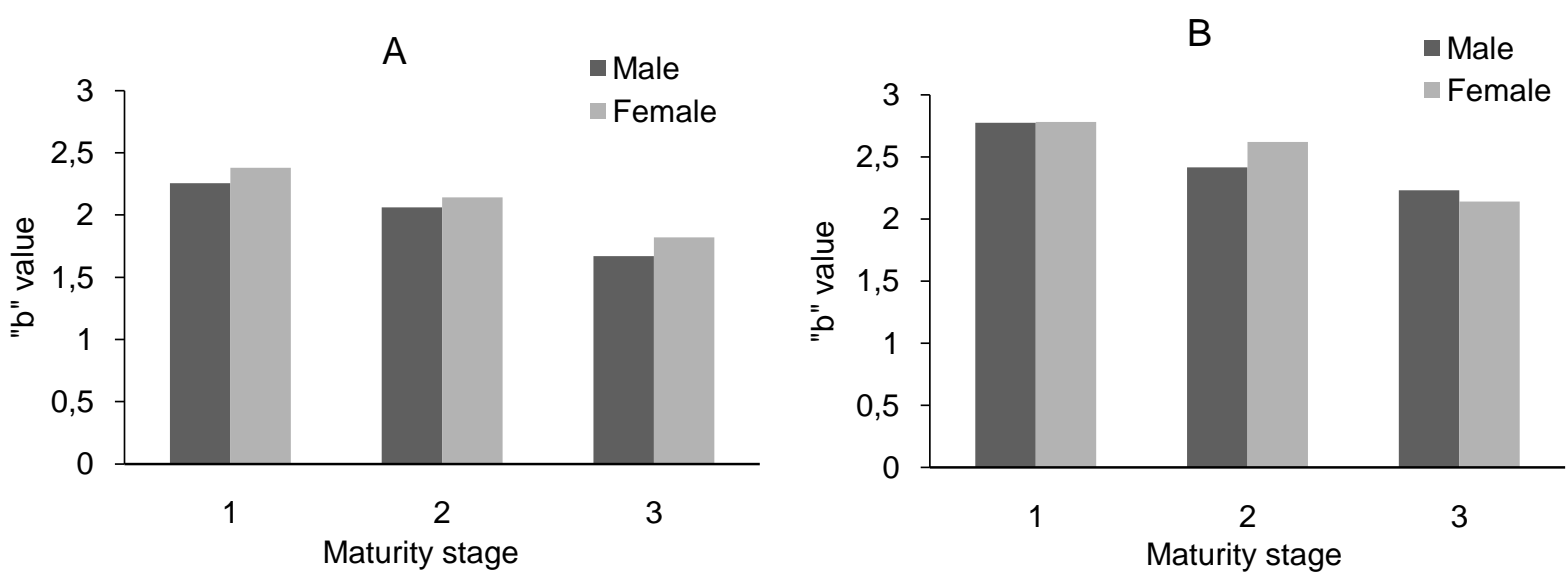

Figure 3 - Relationship between different maturity stage and growth coefficient "b" value of $P$. chinensis and $P$. duvaucelii $(\mathrm{A}=P$. chinensis; $\mathrm{B}=P$. duvaucelii).

Both sexes of $P$. chinensis stage-III indicated weak allometry because lowest "b" value 1.671 and 1.820 for male and female stage-III respectively (Table 1 and Figure 3A). According to ' $b$ ' value observation female's growth rate faster than males. In $P$. duvaecelii showed "b" value $>2$ but this value was decreasing with attaining their stage-I to stage-III (Figure 3B). However, males stage-III "b" value was 2.231 and 2.141 for female stage-III which was the lowest value among other maturity stage I, II (Table 2 and Figure 3B). During stage-I, growth pattern almost same for both sexes; females growth rate faster than males during stage-II and during stage-III, male's growth rate more than females (Figure 3B).

The short life-span, sexual dimorphism and nonasymptotic growth displayed by Photololigo sp in northern Australia. Though, $P$. chinensis were showed males obtain bigger size than females (Jackson and Choat, 1992). It was found that $P$. chinensis squid species have a close relationship between their maturation and size; though some females Photololigo sp were immature and make delay be mature even with their larger mantle length (Jackson, 1993). Similar attributes found that mature Photololigo edulis size range less than their typical maturation size in Japan (Natsukari and Tashiro, 1991). Unlikely, Loligo vulgaris reynaudii both sexes showed that immature size range was larger than typical maturation size in South Africa (Augustyn et al., 1992). Large range of ML of mature Loligo gahi loliginid specimen was observed; males 7.1 to $>30 \mathrm{~cm}$ and females 9.8 to $>22 \mathrm{~cm}$ (Hatfield et al., 1990).

This study showed mature males size range $7.9-42.2 \mathrm{~cm}$ and females mature size range $14-24.2 \mathrm{~cm}$ of $P$. chinensis where $P$. duvacelii mature males size range $7.3-22 \mathrm{~cm}$ and females mature size range $7.3-17.1 \mathrm{~cm}$. Though, mature males and females $P$. chinensis typical size ranges were $16 \mathrm{~cm}$ and $14 \mathrm{~cm}$ respectively (Chotiyaputta, 1993) and $P$. duvacelii 9-13 cm for females and 7-15 cm ML for males (Mohamed, 1993). Therefore, this stud exhibited, mature males $P$. chinensis ML smaller than typical maturation ML and $P$. duvacelii showed larger range of mature ML than their typical maturation size range which also have proven the above study discussed. Genetic control (Campton and Gall, 1988) and environmental stresses (Chapman and Chapman, 1992) are playing a vital role in a different size at maturity for fishes. Photololigo sp showed phenotypic variation in size at maturity of sexes in Australia (Jakson and Yeatman, 1995). However, the environmental, behavioral, or genetic factors or combination of all three factors are responsible for noticing the variation in size at maturity.

Some scientists studied about the length-weight relationship of both of these species and found variation of their growth pattern in the different geographical area and different years. The overall $P$. chinensis growth coefficient value "b" were 2.579 in Marudu, Sabah, Malaysia (Siddique et al., 2014), and 2.027 in the Gulf of Thailand (Suppanirun et al., 2011). Similarly, for $P$. duvaucelii "b" value estimated for males 1.613 and females 1.672 were 
calculated in the West coast of India (Mishra et al., 2012). Recently it was found in Gulf of Suez Egypt that 'b' value was 1.958 for males and 2.416 for females (Sabrah et al., 2015). Hence, this study found how the growth value "b" change with attaining new maturity stage which are new finding and different from the above study only for males and females. According to the aforementioned, their study was either on overall species or on the basis of separate sexes and how changes their growth pattern stage to stage. From this study it was proved the growth value " $b$ " value is inversely related to attaining their maturity stage.

\section{CONCLUSION}

It can be concluded that most of case size is the factor to assume the maturity, but is also depend only the internal body activities. Significant change of growth with attaining new maturity stage and it is ultimately affecting the growth pattern of a mature species. However, this finding can be useful in future study as well as for management of these resources.

\section{ACKNOWLEDGEMENTS}

The authors are grateful and sincerely thankful to Sriwita Chaibundi and Nopparattana Ruangpatikorn who taught detail biological knowledge about these squid species. Thanks to all of the crew members of "MV PRAMONG 9" for their assistance during field sampling. Sincerely say thanks to the Graduate School, Prince of Songkla University for supporting research fund. Thanks to Mr. Jonathan Wayne Constablfor checking and correcting the English.

\section{REFERENCES}

1. Augustyn, C. J., Lipinski, M. R., and Sauer, W. H. 1992. Can the Loligo squid fishery be managed effectively? A synthesis of research on Loligo vulgaris reynaudii. South African Journal of Marine Science, 12: 903-918.

2. Campton, Donald, E., and Gall. G. A. E. 1988. Responses to selection for body size and age at sexual maturity in the mosquitofish, Gambusia affinis. Aquaculture, 3: 221-241.

3. Chantawong, P., Suksawat, C. 1997. Cephalopod distribution and abundance in the northern part of Phang-Nga Province, Thailand. In Hylleberg, J., (Eds.), Proceedings of the 7th Workshop of the Tropical Marine Mollusc Programme, TMMP, on Central and West Java, Indonesia conducted at IPB, UNDIP, LIPI, 11-22 November 1996, Part 1, 17(1):181-191.

4. Chapman, L. J., and Chapman, C.A. 1992. Variation in the structure of Poecilia gillii populations. Copeia, 908-914.

5. Cheevaporn, V., and Menasveta, P. 2003 Water pollution and habitat degradation in the Gulf of Thailand. Environmental Management of Enclosed Coastal Seas, 47: 43-51.

6. Chottiyaputta, C. 1993. Cephalopod resources of Thailand. Recent advances in Cephalopod Fisheries Biology, pp. 69-78.

7. Hatfield, E. M. C., Rodhouse, P. G., and Porebski, J. 1990. Demography and distribution of the Patagonian squid (Loligo gahi d'Obigny) during the austral winter. Journal du Conseil / Conseil Permanent International pour l'Exploration de la Mer, 46: 306-312.

8. Jackson, G. D. 1993. Seasonal variation in reproductive investment in the tropicallo liginid squid Loligo chinensis and the small tropical sepioid Idiosepius pygmaeus. Fishery Bulletin, 91: 260-270.

9. Jackson, G. D., and Choat, J. B. 1992. Growth in tropical cephalopods: an analysis based on statolith microstructure. Canadian Journal of Fisheries and Aquatic Sciences, 49:218-228.

10. Jackson, G. D., and Yeatman, J. 1995. Variation in size and age at maturity in Photololigo (Mollusca: Cephalopoda) from the northeast shelf of Australia. Fishery Bulletin, 94: 59-65. 
11. Jereb, P., and Ragonese, S. 1995. An outline of the biology of the squid Illex coindetii in the Sicilian Channel (Central Mediterranean). Journal of the Marine Biological Association of the United Kingdom, 5: 373-390.

12. Jereb, P., and Roper, C.F.E. 2010. Cephalopods of the World. An annotated and illustrated catalogue of cephalopod species known to date, vol. 2. Myopsid and Oegopsid Squids. FAO Species Catalogue for Fishery Purposes, 2(4): 262, 605.

13. Le Cren, E.D. 1951. Length-weight relationship and seasonal cycle in gonad weight and condition in perch (Perca fluvitialis). Journal Animal Ecology, 20: 201-219.

14. Mishra, A. S., Nautiyal, P., and Somvanshi, V. S. 2012. Length-weight relationship, condition factor and sex ratio of Uroteuthis (Photololigo) duvaucelii (d'Orbigny, 1848) from Goa, west coast of India. The Marine Biological Association of India, 54(2): 65-68.

15. Mohamed, K. S. 1993. Spawning congregations of Indian squid Loligo duvaucelii (Cephalopoda: Loliginidae) in the Arabian Sea off Mangalore and Malpe. Indian journal of marine sciences, 22: 172-175.

16. Natsukari, Y., and Tashiro, M. 1991. Neritic squid resources and cuttlefish resources in Japan. Marine Behaviour and Physiology, 18: 149-226.

17. Pauly, D., and Christensen, V. 1993. Stratified models of large marine ecosystems: a general approach and an application to the South China Sea. (eds. K. Sherman, L. M. Alexander and B. D. Gold), Large marine ecosystem: stress, mitigation and sustainability. AAAS, Washington, D.C., pp.148-174.

18. Petrakis, G., and Stergiou, K. I. 1995. Weight-length relationships for 33 fish species in Greek waters. Fisheries Research, 21: 465-469.

19. Piyakarnchana, T. 1989. Yield dynamics as an index of biomass shifts in the Gulf of Thailand. In: Biomass yield and geography of large marine ecosystems. (eds. K. Sherman and L. M. Alexander) AAAS Symposium 111. Westview Press Inc., Boulder., pp. $95-142$

20. Sabrah, M. M., El-Sayed, A. Y., and El-Ganiny, A. A. 2015. Fishery and population characteristics of the Indian squids Loligo duvauceli (Orbigny, 1848) from trawl survey along the north-west Red Sea. Egyptian Journal of Aquatic Research 3(41):279-285.

21. Siddique, M. A. M., Arshad, A., and Nurul Amin, S. M. 2014. Length-weight relationships of the tropical cephalopod Uroteuthis chinensis (Gray, 1849) from Sabah, Malaysia. Zoology and Ecology, 24: 215-218.

22. Silas, E. G., Rao, K. S., Sarvesan, R., Nair, K. P., and Meiyappan, M. M. 1982. The exploited squid and cuttlefish resources of India. A review Marine Fisheries Information Service, Technical and Extension Series, 34, 1-16.

23. Supongpan, M., and Sinoda, M. 1998. Sexual maturity size of Indian squid Loligo duvauceli in the Gulf of Thailand. Bangkok Marine Fisheries Development, Technical Paper, 6:1-9.

24. Suppanirun, T., Songkeaw, N., Khrueniam, U., and Pinputtasin, C. 2011. Reproductive Biology of Indian squid, Photololigo duvaucelii (d'Orbigny, 1835) and Mitre squid, P. chinensis (Gray, 1849) in the Gulf of Thailand. Technical paper No.2.

25. Voss, G. L., and Williamson, G., 1971. Cephalopods of Hong Kong. Hong Kong Government Press, 138pp. 